popularity for being more sensitive in showing paramagnetic tissues compared with the standard T2* GRE. This was initially commercialized as susceptibility-weighted imaging (SWI) by Siemens (Malvern, PA) MRI. SWI uses additional phase information to increase the sensitivity. ${ }^{2}$ We previously reported evidence for higher sensitivity of SWI over GRE. ${ }^{3}$ Since then, it is gradually replacing T2*-GRE in clinical imaging, especially in settings where Siemens MRI is used. Due to licensing and patent issues, different MRI vendors are often forced to slightly modify a sequence technique to avoid infringement. To provide an equivalent ESI technique, General Electric (Milwaukee, WI) modified the T2*-GRE by multiecho acquisition and postprocessing reconstruction as weighted average in its MRI and called it SWAN. Similarly, Philips (Andover, MA) MRI uses a different postprocessing technique called phase difference enhanced imaging (PADRE) to combine the phase information. The different ESI are probably superior to T2*-GRE. It would be interesting to compare ESI techniques from different vendors, comparing apples to apples.
Author Response: Michele A. Scully, Rochester, NY: We appreciate Dr. Nandigam's further explanation about ESI techniques and clarification that-like a number of other MRI methods - they are identified and performed differently by different MRI vendors. Neurologists should be aware of the variety of MRIenhanced susceptibility sequence names and that each is performed in slightly different ways. We concur with Dr. Nandigam that ESI should replace T2*-GRE and that various techniques used by the different MRI vendors for specialized MRI sequences should be rigorously compared.

(C) 2013 American Academy of Neurology

1. Scully MA, Yeaney GA, Compton ML, Berg MJ. SWAN MRI revealing multiple microhemorrhages secondary to septic emboli from mucormycosis. Neurology 2012;79: 1932-1933.

2. Haacke EM, Mittal S, Wu Z, Neelavalli J, Cheng YC. Susceptibility-weighted imaging: technical aspects and clinical applications, part 1. AJNR Am J Neuroradiol 2009;30:19-30.

3. Nandigam RN, Viswanathan A, Delgado P, et al. MR imaging detection of cerebral microbleeds: effect of susceptibilityweighted imaging, section thickness, and field strength. AJNR Am J Neuroradiol 2009;30:338-343.

\title{
CORRECTION
}

\section{Management of carotid stenosis in women: Consensus document}

In the article "Management of carotid stenosis in women: Consensus document" by P. De Rango et al. (Neurology 2013;80:2258-2268), there is an error in the author list. The third author's name should read Didier Leys, MD, PhD.

The authors regret the error. 


\section{Neurology}

\section{Management of carotid stenosis in women: Consensus document Neurology 2013;81;200 \\ DOI 10.1212/WNL.0b013e3182a06bc0}

This information is current as of July 8, 2013

\section{Updated Information \&} Services

Permissions \& Licensing

Reprints including high resolution figures, can be found at: http://n.neurology.org/content/81/2/200.full

Information about reproducing this article in parts (figures,tables) or in its entirety can be found online at:

http://www.neurology.org/about/about_the_journal\#permissions

Information about ordering reprints can be found online:

http://n.neurology.org/subscribers/advertise

Neurology ${ }^{\circledR}$ is the official journal of the American Academy of Neurology. Published continuously since 1951 , it is now a weekly with 48 issues per year. Copyright @ 2013 American Academy of Neurology. All rights reserved. Print ISSN: 0028-3878. Online ISSN: 1526-632X.

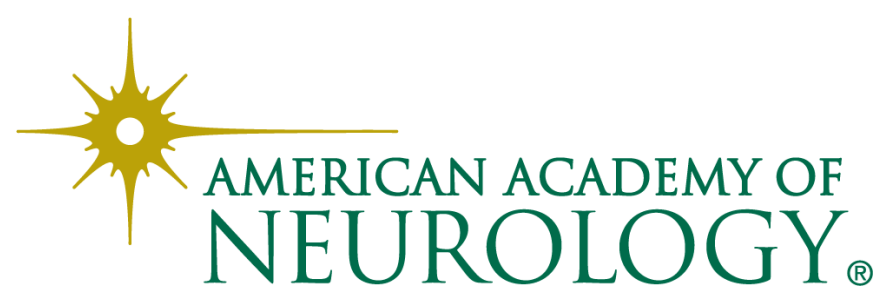

